\title{
The Inheritance of Malay Palace Dance in Malaysia and Yogyakarta Classical Dance in Indonesia
}

\author{
Muhammad Fazli Taib Bin Saearani \\ Fakulti Muzik dan Seni Persembahan, Sultan Idris Education University, Malaysia \\ Sultan Idris Education University 35900 Tanjong Malim Perak, Malaysia \\ ॠE-mail: fazli@fmsp.upsi.edu.my \\ Agus Cahyono \\ Department Sendratasik, Semarang State University, Indonesia \\ Sekaran Campus Gunungpati, Semarang 50229, Central Java, Indonesia
}

Received: April 9, 2016. Revised: June 3, 2016. Accepted: July 2, 2016

\begin{abstract}
The background of this study is the effort of solving the inheritance problem faced by Malaysia in the case of Malay Palace dance which is currently in decline. This study is done by using best practice from the The Development and Inheritance of Yogyakarta Classical Dance (TKGY) done by the Ngayogyakarta Hadiningrat Palace and some formal and non-formal institutions in Yogyakarta, Indonesia. TKGY is chosen as it is viewed to have positive life in classical Palace dance and involve various actors and clear strategies. For three years, the researcher has done the research by observing the inheritance context (TKGY) to identify preservation phenomena done in Yogyakarta. This research is using a qualitative approach. The data are collected by doing indepth interviews with some leaders of the main studios in Yogyakarta and Malay Palace dance choreographers in Malaysia. The result of the research shows that there are some similarities and differences between Malay palace dance in Malaysia and Yogyakarta classical dance. Some strategies have been used to describe how the Malaysian government adopts inheritance strategies (TKGY) used by actors in the inheritance discourse (TKGY).
\end{abstract}

Keywords: Inheritance; Yogyakarta classical dance; Malay Palace dance

How to Cite: Saearani, M. F. T. B \& Cahyono, A. (2016). The Inheritance of Malay Palace Dance in Malaysia and Yogyakarta Classical Dance in Indonesia . Harmonia: Journal of Arts Research And Education, 16(1), 75-86. doi:http:/ / dx.doi. org/10.15294/harmonia.v16i1.6145

\section{INTRODUCTION}

Malay Palace dance in Malaysia has relatively slow movement starting with kneeling position and bowing, and moving slowly to standing position, and careful and sensitive hand and arm motions. The way the dancers facing downward or along with their hands show their respects to Sultan. There are only two Malay palace dances in Malaysia which are in special status: Asyik dance and Joget Gamelan dan- ce (Tharuwat, 2011: 35). There are other palce dances like Terinai, Mangadap Rebab and Layang Mas, but they are not special. Asyik dance and Joget Gamelan dance become a part of curriculum in Palace Dance lesson (Pusat KoKurikulum dan Pemajuan Pelajar, 2009, pp. 75-76). Some art groups have tried to pass down the palace dance in some events, in Malaysia and in other countries. Therefore, the two dances will be the focus of discussion in this paper. 


\section{METHOD}

This research is using a qualitative approach. The data are collected by doing observation, interview, and documentation. In-depth interview was done to the main leaders of studios in Yogyakarta and palace dance choreographers in Malaysia. The data were analyzed using interactive model: data reduction, data display, and data verification. The data validity in the research was done to check its validity and reliability, and its trustworthiness (Rohidi, 2011, p. 218).

To keep its validity and trustworthiness, triangulation was done. It means it was done by checking the data from different sources. Based on the various data, the data are described, categorized, and analyzed to reach conclusions. The triangulation technique was done by comparing data from different sources to compare different perspectives on the data.

\section{RESULT AND DISCUSSION}

Asyik dance was developed in Kesultanan Pattani in Semenanjung Utara in the era of Ratu Kuning, 1635-1649/1688), Ratu Ungu 's daughter (1624-1635), and Ratu Biru's niece (1616-1624). She was the fourth queen after Sultah Bahdur (15731584) who had three sisters who became queens respectively (Ratu Hijau, Ratu Biru, and Ratu Ungu). In the era of the four queens, Kesultanan Pattani reached its glory (Conlon, 2012, p. 50).

It contributed to peace which might promote dance creation oriented to hedonism. However, the reign ended badly. There are two history version about the end of Kesultanan Pattani reign. The first version told that Pattani was invaded by Kesultanan Kelantan in the south by Raja Sakti I. The second version told that Pattani was helped by Kesultanan Kelantan to send troops from Ayodhya (Siam) away which attacked from the north. Whichever version was right, Asyik dance was transmitted from Pattani to Kelantan.

Based on Pattani folklore, Asyik dan- ce was created on the order of a king who was sad because his bird flew away. He tried to find it, but he could not. The king wanted to watch a dance which looked like the flying bird (Manaf, 2002, p. 423). The dance was named Asyik dance because the dance movement and the female dance sitting position are interesting to watch, especially the male ones. However, some people said that asyik is not an adjective, it is the names of palace dayang in Kelantan on the 14 century (Sahimi, 2005, p. 158).

Other people said that asyik means a lover, and it is shown by Puteri Asyik character as the main dancer in the dance. On its journey, Asyik dance was developed in Istanan Balai Besar Kelantan, as a devisor of Kesultanan Pattani (Sahimi, 2005, p. 158). The development was then performed in the Palace of Yang Dipertuang Agung on 30 and 31 August 1957, at the house of the prime minister on 1st September 1957, and general shows in Kuala Lumpur on 5-6 September 1957, right after Malaysia proclaimed its Independence from England on 31st August 1957 (Tharuwat, 2011, p. 24). The innovation was done on the dance movement, choreography, and costumes which put movement practicality forward. Thailand influence can be seen in the dancer's costumes. Thai dancer's costumes consist of three parts: dress, body accessories, and head accessories (Tharuwat, 2011, p. 32). Thai dress for female dancers are usually open on the upper part of the body and on the hands, and long silk dress, and scarf (Thomas, \& Sydenham, 2008). The body accessories are varied, the ones in golden colour and head accessories. The head accessories can be gold accessories like a crown or simple accessories, like flowers (Manaf, 2002, p. 423). In Malay culture, the dress is considered too open.

Based on the reasons, the next development (when Moslem Party was in reign) was in the dancer's costume which became closer tertutup and longer. The upper part of the body and arm are closed. The hair is also closed with hijab. The dancers may not wear hijab, but their hair should be in 
a bun. Accessories are not worn on every part of the body, only on the head on the upper part of chest. There are two main styles of Asyik dance: Asyik Kijang Mas and Asyik Sasang (Tharuwat, 2011, p. 29). Asyik Kijang Mas has more songs and is associated with Makyong dance and Manora dance. Kijang Mas itself is one of 2030 songs of Makyong song (Takari, 2013, p. 134).

Asyik Sasang is a variation of Asyik dance which has movements which in the contrary of Asyik Kijang Mas dance. Sasang itself meand upside-down. Asyik Sasang is more developed and is named after animals' movement, like itik berenang (swimming duck), gajah amok (angry elephant), burung merpati (dove), or ayam patah sayap (broken-wing chicken). Asyik dance accompanied with three gongs, 11 gendangs (gedombang asyik), a big hanging gong, and Gamelan song (Ang, 2002, p. 19). The dance starts with ten dancers sitting on their legs. After that, Puteri Asyik enters the stage and starts the dance (Kementerian Pengajian Tinggi, 2013, p. 24).

The problem faced by Asyik dance is a linguistics problem which fades the dance identity away. Although we have a clear guidance on how to differ Asyik dance with other dances, people's understanding on the term 'asyik' is more on an adjective, which makes them think that any interesting dances is called asyik dance. For example, the show: "Asyik: the Beauty of Classical Dance" from ASWARA on December 2007 is a compilation of dances from different ethnics in a story, and Asyik dance is performed as a dance. The same thing was on the ASWARA show on March 2013 entitled "Malam Asyik" showed Joget Gamelan, Makyong, Bharatanatyam, Silat, and at the end Asyik (Eunice Au, 2014).

Based on the description above, we can see that Asyik dance has passed three periods. The first period was when it was created in Kesultanan Pattani. It is true that Pattani is a Kesultanan, but the influence of Siam was very strong and the materialism background pushed the Sultans to live in hedonism as a result of the success on trading, makes the first Sayik dance had Siamese cultural features and erotic.

The second period was Islamization period which occured on the more modern era, around the era of Kesultanan Kelantan or Malaysia Kingdom. Islamization brought changes to the dance to become more social than intimate between individuals.

The third period was a period when multiculturalism became stronger in the last decade. In this period, Asyik dance lost its identity as a palace classical dance because practically, the composition has become multicultural and semiotically which defines asyik as an adjective than a character. The nuance is wider, that is nationality. We can conclude that Asyik dance has a wider meaning, and unfortunately, had to sacrifice its identity as a palace classical dance. The scope of Asyik dance is also changed from palace dance to dance with religious identity, and then to a dance with nationality identity. Along with the meaning changes, Asyik as a character (Putri Asyik) becomes Asyik as an adjective (enjoyful/interesting).

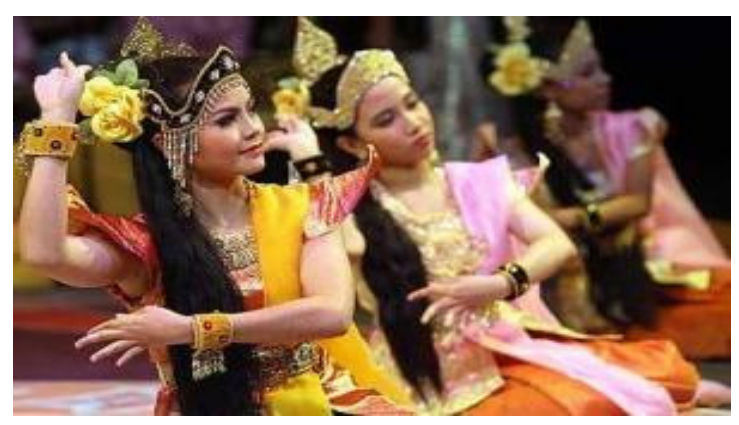

Figure 1. Asyik dance with Siamese Costume (Photo by: Muhammad Fazli Taib, 2014)

\section{The Condition of Joget Gamelan Istana Pahang and Terengganu Dance}

The second dance is Joget Gamelan. Joget Gamelan is from Pahang and Terengganu. The name of Gamelan is from Malay Gamelan played for the dance. Malay gamelan is different from Javanes gamelan, from the instruments, scale, and the music. One set of Malay Gamelan consists of one 
gendang, kerumong, kenong (five gongs like big vase), two saron (barung and peking), one gambang, and gong suwukan (one big hanging gong with high tone), and gong agung (one big hanging gong with low tone). Gendang becomes the tone, sarong barung becomes the melody, while the big gng and kenong give music time signal, and others are the ornaments (Matusky, 2008, p. 239).

Joget Gamelan was originally from Yogyakarta Palace in the middle of the 18th Century (D'Cruz, 2011: 2). In 1811, Serimpi and Bedhaya dancers, and Gamelan players were taken from Java to Istana Kuning Kesultanan Riau-Lingga in Penyengat Island to have a performance at a royal wedding. As Kesultanan Riau-Lingga covered Semenanjung area, Joget Gamelan transmission to Pahang area happened soon. However, the Gamelan music group in Lingga got faded as soon as Sultan Lingga reign ended, Abdul Rahman Muadzam Shah II bin Almarhum Raja Muhammad Yusuf al Mahdi (1885-1911), destroyed his own palace to avoid the Dutch taking over the palace and he went to Singapore in 1912 (Takari, 2013, p. 7). The inheritance process in Pahang was started by Sultan Ahmad Muadzam Syah (1863-1909). It was managed by the queen Wan Fatimah and his second wife, Che Zubedah (Omar, 2005 , p. 5). The preservation process in Pahang was done directly by Sultan who enthusiastically danced the dance and documented the dance. Joget Gamelan was performed in many ceremonies in the palace like inauguration, wedding, king's birthday, and baby delivery.

The transmission process to Terengganu area was done in at least two occasions, both royal weddings (Yong, 2010:, pp. 171-175). The first one was on the Tengku Long's wedding, the daughter of Sultan Ahmad from Pahang, with Sultan Zainal Abidin III (1881-1918) from Terengganu, in 1885. Since then, Joget Gamelan had become famous in Terengganu area and became a part of Terengganu and $\mathrm{Pa}$ hang Kingdoms' ceremony. In 1895, Sir Frank Swettenham, an English officer in
Malaya, wrote that Joget Gamelan dance is a dance with special accompaniment which looked like real music (Yong, 2010, p. 171). The dance he watched was Joget Gamelan performed in 1895 Istana Pekan, Pahang (Omar, 2005, p. 3).

The second transmission was on Tengku Ampuan Mariam's wedding, the other daughter of Sultan Ahmad (from his marriage with Che Zubedah), with Teng$\mathrm{ku}$ Sulaiman (who then became Sultan Sulaiman Badrul Alam Shah (1920-1942)), the second son of Sultan Zainal Abidin, in 1914 (Yong, 2010, p. 171). Unfortunately, in the same year, Sultan Ahmad passed away and Joget Gamelan faded away in Pahang.

Che Zabedah then followed her daughter moving to Istana Maziah Terengganu. One year later, a set of Gamelan was taken from Pahang to Terengganu. In Terengganu, Tengku Mariam tried to revive Joget Gamelan dance by teaching Joget Gamelan to the youth there. On 21 May 1920, right after Tengku Sulaiman became Sultan, two ex dancers from Pahang, Yang Khoja and Cik Meriam were brought to Terengganu to teach Joget Gamelan. Famous gamelan players from Pahang like Encik Wan Mohd, Encik Wan Ahmad, Pak Salleh, and Encik Ahin, came along with them (Wahidah, 2008, p. 5). This kept Joget Gamelan victorious and became an exclusive Malay Palace dance in the kingdom, for sacred ceremonies and other events like accepting guests. In 1925, Wilkinson wrote how Joget Gamelan dance was modified to the audience from European countries at that time (Yong, 2010, p. 171).

Tengku Ampuan Mariam kept teaching dancers, gamelan players, and created her own orchestration. All models of Joget Pahang dance were created by Tengku Ampuan Mariam. Sultan Sulaiman tried his best to differ Joget Gamelan in Pahang and Joget Gamelan in Terengganu. So far, the dance's name becomes Jeget Pahang, but Sultan Sulaiman named Joget Gamelan in Pahang as Joget Gamelan Pahang, and Joget Gamelan in Terengganu as Joget Gamelan Terengganu (Wahidah, 2008, p. 5). Joget Gamelan dancers were called Bu- 
dak Joget or Anak Joget. However, Sultan was also a gamelan player and a gamelan teacher, while his queen is a dancer and a dance teacher at the same time. In 1932, Istana Kolam was built and became a new place for the Sultan. One year later, the efforts of developing Joget Gamelan dance were done in this place (Omar, 2005, p. 17). As a result, in 1935, Joget Gamelan Terengganu was performed in Istana Bangkok (D'Cruz, 2011, p. 8).

One year later, Sultan Sulaiman had already had a set of gamelan for performance. Isolation was done in this situation because Joget Gamelan dance was always performed in the palace. Because of it, the preparation of the performance always became busy days. From the history above, inheritance process happened explicitly, from Java Kraton, through Riau-Lingga, arrived in Pahang, and finally arrived in Terengganu and was being preserved there. A unique transmission happened between Pahang and Terengganu when, in 1885, the transmission marked the beginning of Jiget Gamelan in Terangganu, and the transmission in 1914 marked the end of Joget Gamelan in Pahang. However, the journey of Joget Gamelan did not end. In 1941, Japan colonialized South East Asia and brought the WW II to this area. In 1942, Sultan Sulaiman passed away, and Tengku Mariam, the dancers, and the gamelan players moved to Istana Kolam. By that time, the inheritance process of Joget Gamelan dance in Terengganu finally stopped, marked by the moving of Tengku Mariam, the dancers, and the gamelan players. In the 1960s, Mubin Sheppard, a humanist, prolific author, and world recorder, Persekutuan Tanah Melayu, revealed he existence of Joget Gamelan on his sculpture in Istana Kolam Terengganu. By chance, he met Tengku Ampuan Mariam and found the gamelan set in the palace. The finding became political problem between Kasultanan Pahang and Terengganu. In the end, the Gamelan set was returned to Pahang in 1973 by agreement between the two kingdoms. Then, the Gamelan set was kept in the Pahang Museum in Pekan (Wa- hidah, 2008, p. 5).

Realizing that there were the dancers and gamelan players who took part on Joget Gamelan's performance in Terengganu palace, Mubin organized a meeting with the dancers and gamelan players. Right after that, Tengku Mariam joined Mubin Sheppard to raise Joget Gamelan (Yong, 2010, p. 172). In 1967, the dancers and gamelan players were invited to perform at Istana Kolam in front of royal guests. In 1969, International conference on the South-East Tradition Drama and Music at University of Malaya, Kuala Lumpur was held and became the first moment for Joget Gamelan dance to be performed in public. In 1971, after a bloody tragedy in Malaysia, Malaysian Kingdom imposed National Culture Policy. One of the policy put Joget Gamelan dance as one of an inherited Malaysian culture. Since then, Joged Gamelan has been performed not only in Terengganu and Pahang but also all over Malaysia. This dance is taught at schools and performed in government offices, televisions, and other places. Tengku Ampuan Mariam's granddaughter, Tengku Hilmi Suleman bin Tengku Abdul Halim Syah, taught and trained gamelan in many places in Kuala Lumpur and Selangor (Omar, 2005, p. 41).

In 1990s, Gamelan Club was established by Sunetra Fernando who was graduated from Sekolah Tinggi Seni Indonesia, Solo. Gamelan Club is a nonformal group focuses on kerawitan aspect of Joget Gamelan, and mixes them become multicultural music, bot from the players and the instruments. It used not only Malay gamelan but also Javanese and Balinese gamelan (Yong, 2010, p. 172). In 1997, Gamelan Club made a full concert showing the innovative contemporary version for public.

In 1998, a year later, Fernando established a new group which was completely different from gamelan tradition, that is by making a group consisting of female players. The group named Rhythm in Bronze shows the spirit of innovation of the gamelan aspect of Joget amelan dance. The interesting fact is that this condition 


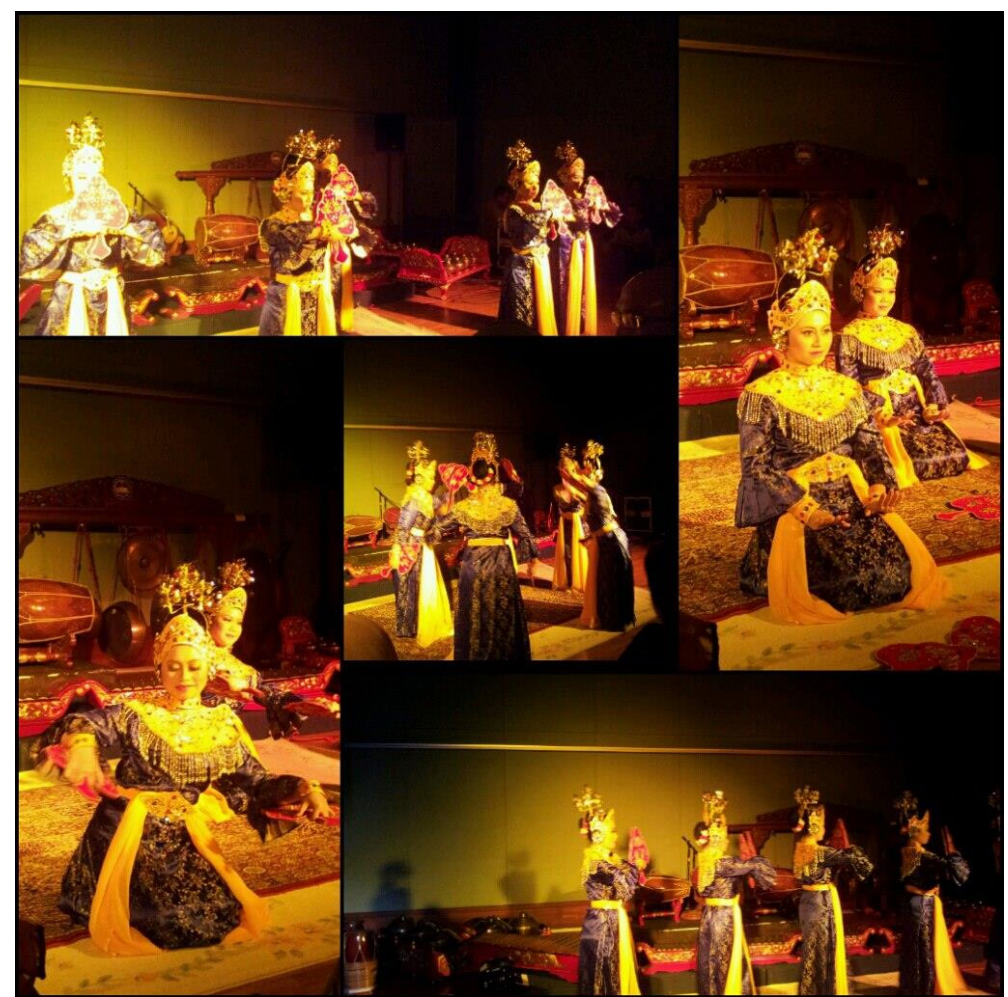

Figure 2. Joget Gamelan, from Istana Terengganu and Pahang, Malaysia (Photo by: Muhammad Fazli Taib, 2013)

was not found in the dance aspect of Joget Gamelan dance itself.

The Joget Gamelan dance's story was mostly taken from the story of Panji from Java. Some part were from activities in around the palace. The dance is opened with gamelan music entitled Ayak-ayak then followed with Togok, Timang Burung, Lambang Sari, Perang, Geliong, Ketawang, Lohor, Topeng, Arak-Arak, Wani-wani and Lancang Kuning (D'Cruz, 2011, pp. 11-12). The first six movements, starting from Ayak-Ayak until Geliong had existed since Sultan Sulaiman era. If the dancers do all movements, it will take 5 to 6 hours to dance. Meanwhile, Mohd Nefi Imran bin Djamaan enrolled 75 fragments of dances from the compilation of Joget Gamelan Terengganu (Imran, 2003). Table 1.1 shows 20 terms used in Joget Gamelan Terengganu dance and the definition.

From the description above, we can see that Joget Gamelan is a series of dances like wayang wong. Mohd Anis Mohd Noor states that Joget Gamelan can be said as theatrical drama if it is more organized as it has a lot of standard movements, like jari menanti, pecah jari (melentik plus sepit ketam, done with one or two palms), jari sepit ketam (fore finger and thumb sticking and also the other three fingers so they form scissors or sepit kepiting), jari sepit sabuk, sembah, campak lenggang (throwing scarf or wooden fan to the side), berkisar melemak (bending the body back until the head touches the floor), sitting on two heels, sitting on one or two knees, timpuh katak (sitting on two thighs and the knees are folded at front), and timpuh sila (crosslegged sitting). Campak lenggang includes: regular campak lenggang, sambut gong campak lenggang, and melayah campak lenggang. They are done while sitting and standing. Sitting position is done with timpuh katak and sitting on two heels (Omar, 2005: 103).

As an elite dance, Joget Gamelan also looks rigid in the movement. There is almost no improvisation in dancing except on the dancers' position mpst of whom are female. It is influende by seniorit or leadership in the show. The influence of TKGY can be seen in the dance. Besides the Java- 
Table 1. Fragments on Joget Gamelan dance and its definition

\begin{tabular}{|c|c|}
\hline Term & Definition \\
\hline Arak-arak & A dance showing a trawling person \\
\hline $\begin{array}{l}\text { Ayak-ayak } \\
\text { Dalam }\end{array}$ & Used as closing if Sulang Arak or Perang is not done \\
\hline Ayak-ayak Mula & Fragment of the first dance \\
\hline Barong, Baung & $\begin{array}{l}\text { Telling about Inu sitting side by side and being entertained by } \\
\text { Gambuh }\end{array}$ \\
\hline \multirow[t]{2}{*}{ Bujam Emas } & Bujam is a place for sirih leaves, describing a time when Raden \\
\hline & $\begin{array}{l}\text { Galuh was trying to find Nenek Kebayan and took flowers in the } \\
\text { garden }\end{array}$ \\
\hline Engkok & $\begin{array}{l}\text { Describing a princess flying to heaven, followed by her husband, } \\
\text { but her husband was lost in the jungle. He cut trees and made his } \\
\text { way to heaven. From heaven, he threw a ring to Buyung Inang- } \\
\text { Inang who was taking water in the pond. }\end{array}$ \\
\hline Galah Ganjur & Ganjur is a spear \\
\hline Gambuh & $\begin{array}{l}\text { Telling a story about Raden Menteri who chose Raden Puteri and } \\
\text { shot a bird when Raden Putri was weaving }\end{array}$ \\
\hline Geliung & Geliung is a big ship in 16 century \\
\hline Ketawang & Ketawang is a song in Javanese gamelan \\
\hline Lolo & Lolo means peeping \\
\hline Lonang & Lonang means nona fruit \\
\hline Mulih, Pemulih & Mulih means going back home in Javanese \\
\hline Perang Selinan & Big wars, including betul war, Geruda war, and Seri Rama war \\
\hline Rangu-Rangu & $\begin{array}{l}\text { Welcoming Gambuh when he went back to Kuripan with Raden } \\
\text { Inu }\end{array}$ \\
\hline Sembawa Balik & Betara guru went to Tasik to revive Gambuh who passed away \\
\hline Serakas Tunggal & Inu was playing in Balai when struck by Betara Guru \\
\hline Seri Rama Balik & $\begin{array}{l}\text { A war between Garuda and Harimau, and the commander Seri } \\
\text { Rama }\end{array}$ \\
\hline Timang Inu & Gambuh shot an arrow to Nakus \\
\hline Wani-Wani & The princess was taking a bath in a pond \\
\hline
\end{tabular}

nese gamelan modification, other modifications are on the use of long scarf, a fan on the hand, and hand and head movements which are like TKGY (Nor, 2004: 66). The Malay style can be seen on the body swing movement to the slooping shoulder.

The similarities and Difference of Malay Palace Dances in Malaysia and Yogyakarta Classical Dance
An interesting thing of both dances' history is that they were not originally palce dances from Malaysia. Joget Gamelan from Java is also modified in Malaysia (Nor, 2012: 317). The problem is both are considered to be Malaysian's Malay Identity. This also happen on almost all Palace dances in Malaysia (Alfirafindra, 2012: 78-86). Therefore, we can see that TKGY is from Majapahit Kingdom. 


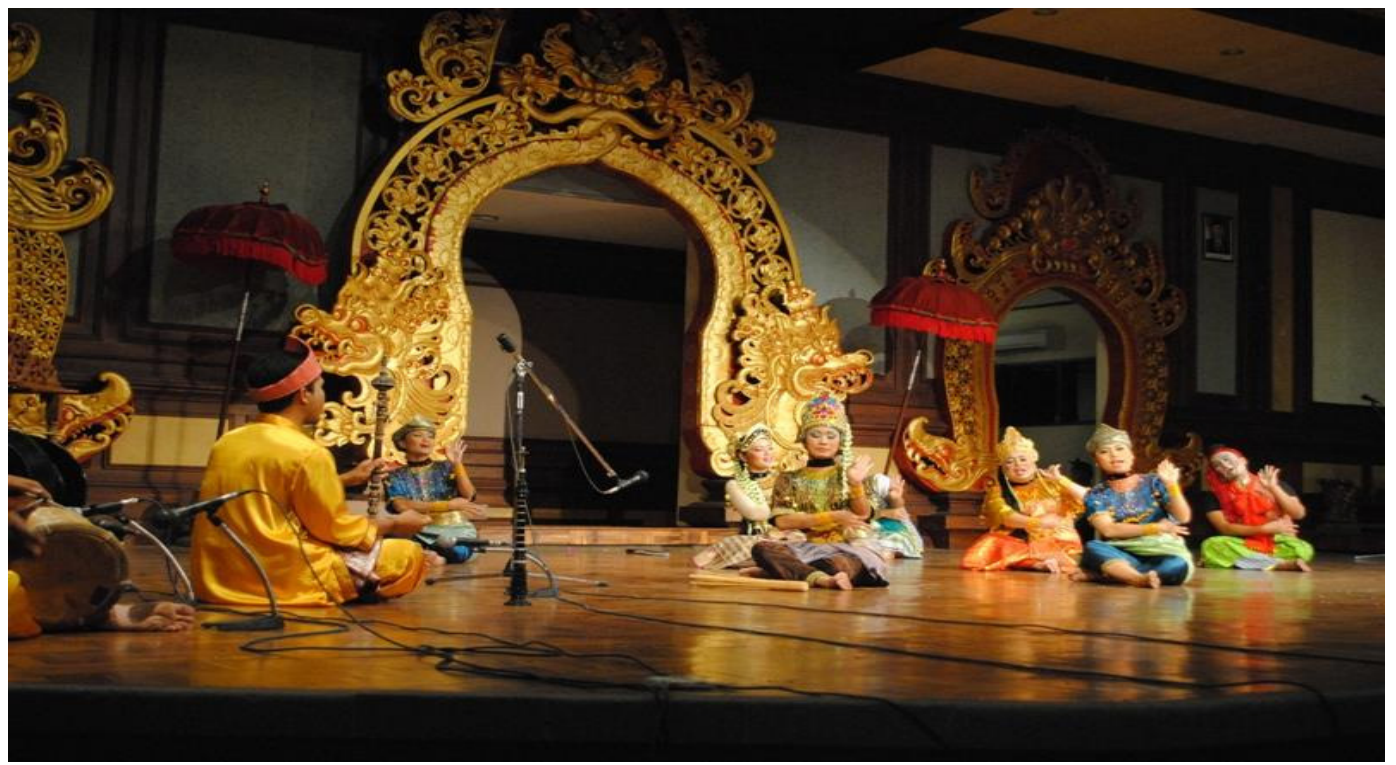

Figure 3. Makyong Show in Pesta Kesenian Bali by the lecturers and students of Universiti Pendidikan Sultan Idris, Malaysia. (Photo by: Muhammad Fazli Taib, 2011)

However, the discourse we have in Indonesia is different form the development discourse in Malaysia. In Indonesia, every dance's location maintains its existence, so people can differ the dances easily, for example: TKGY, Padang dances, and Balinese dances. In Malaysia, the development means cross cultural experience. This makes any Malay dances difficult to preserve their palace dances because they are afraid of ethnic-based jealousy. Ethnical problem is a big problem in Malaysia because the differences among ethnics are based on their origin, socio-economics status, religions, politics, and cultures.

This is why new creation of Malaysia dance contains various ethnics, not only one specific ethnic. In one dance, we can find Malay, Chinese, and Tamil, or even other ethnics. This fades the original identity of the dance away and finally obstructs the development of ethnic-based dance in the ethnic. It will be difficult for a Chinese to learn Palace Malay dance, and vice versa. It will take a very long time to learn the movements in the dance. However, this problem is not faced by TKGY as many students from different ethnics learn TKGY.

The society acquisition process on palace dances does not run perfectly in
Malaysia palaces. Folk dances became the mascots for the palaces along with the palace dances, only one folk performance became a palace theatrical dance, Makyong. However, the truth is still doubtful because the palace does not want to perform the theatrical dance Makyong in the palace anymore. We should realize that this step takes very long time, so many people do not realize that palace dance is actually folk dance.

Howeverhe disclosure of awareness, is also important because after the society considers a dance as a palace dance, the society will be impressed with it when they know that it was originally from folk dance, not created by the palace or imported from other palace. The development stages do not run well either in Malaysia. This is influenced by ethnic political factor. The inheritance of English colonialism was very strong so that it influences Malaysian's multicultural policy. This gives more burden to the majority society perceived as an authority. The majority, Malay, has the burden to share their power with other ethnics, like Chinese, Tamil, and other minor native ethnics. Therefore, Malay society acts carefully by not putting their own culture to be more dominant in the society. 
Table 2. TIM situation in Malaysia compared to TKGY (Table by: Muhammad Fazli Taib, 2014)

\begin{tabular}{|c|c|c|c|}
\hline Dance Names & Asyik dance & Joget Gamelan & $\begin{array}{c}\text { Yogyakata Classical } \\
\text { Dance (TKGY) }\end{array}$ \\
\hline Origin & Pattani, Thailand & $\begin{array}{c}\text { Yogyakarta } \\
\text { Hadiningrat Palace }\end{array}$ & Majapahit \\
\hline Isolation & $\begin{array}{l}\text { Developed inside } \\
\text { Istana Pattani and } \\
\text { Kelantan }\end{array}$ & $\begin{array}{c}\text { Developed in Istana } \\
\text { Pahang and } \\
\text { Terengganu }\end{array}$ & $\begin{array}{c}\text { Developed in Yogya- } \\
\text { karta } \\
\text { Hadiningrat Palace }\end{array}$ \\
\hline Isolation era & $\begin{array}{c}\text { Pattani: 1635-1649 } \\
\text { Kelantan: 1649-31 } \\
\text { August 1957 } \\
\text { National: } 31 \text { August } \\
\text { 1957- 5 September } 1957\end{array}$ & $\begin{array}{c}\text { Riau-Lingga: 1811- } \\
1912 \\
\text { Pahang: 1863- } \\
1914 \\
\text { Terengganu: } \\
\text { 1885-1942 } \\
\text { Nasional: } \\
\text { 1967-1971 }\end{array}$ & $\begin{array}{c}\text { Sultan } \\
\text { Hamengku Buwono I } \\
\text { until } \\
\text { VII: 1755-1899 } \\
\text { (Sultan Hamengku } \\
\text { Bowono VII era when } \\
\text { photography entered } \\
\text { Kraton) }\end{array}$ \\
\hline Exposure & $\begin{array}{l}\text { Merdeka land in } \\
\text { Kuala Lumpur }\end{array}$ & $\begin{array}{c}\text { Kongres } \\
\text { Kebudayaan Nasional } \\
\text { show }\end{array}$ & $\begin{array}{c}\text { Wayang wong } \\
\text { Show with the char- } \\
\text { acters of Pregiwa and } \\
\text { Pregiwati in Yogyakarta } \\
\text { Hadiningrat Palace }\end{array}$ \\
\hline Characteristics & Dualism, simple & Dualism, simple & Monoism, complex \\
\hline Exposure & immanent & immanent & transcendent \\
\hline Exposure Era & $\begin{array}{c}5 \text { September 1957- } \\
\text { now }\end{array}$ & 1971- now & 1899 - now \\
\hline Acquisition & - & - & $\begin{array}{c}\text { Ketoprak, and Beksan } \\
\text { Golek Menak }\end{array}$ \\
\hline $\begin{array}{l}\text { Acquisition } \\
\text { era }\end{array}$ & - & - & $\begin{array}{l}\text { The last half of 19th century } \\
\text { (ketoprak), Beksan Golek } \\
\text { Menak since HB IX - now }\end{array}$ \\
\hline $\begin{array}{l}\text { Develop- } \\
\text { ment era }\end{array}$ & 1957-now & 1971- now & $\begin{array}{c}1918 \text { - (Kridha Beksa } \\
\text { Wirama); 1961- now (SMKI } \\
\text { Yogyakarta) @ (ISI Yogya- } \\
\text { karta) }\end{array}$ \\
\hline $\begin{array}{l}\text { Develop- } \\
\text { ment } \\
\text { an }\end{array}$ & Formal, and nonformal & $\begin{array}{l}\text { Formal, and nonfor- } \\
\text { mal }\end{array}$ & Formal, and nonformal \\
\hline Feedback & $\begin{array}{c}\text { Kementerian } \\
\text { Pelancongan dan } \\
\text { Kebudayaan Malaysia }\end{array}$ & $\begin{array}{c}\text { Kementerian } \\
\text { Pelancongan dan } \\
\text { Kebudayaan Malaysia }\end{array}$ & $\begin{array}{l}\text { Abdi dalem proposal, } \\
\text { Show invitation to the pal- } \\
\text { ace, dance studio, and dance } \\
\text { practice at Kraton }\end{array}$ \\
\hline Feedback era & valid until now & valid until now & valid until now \\
\hline
\end{tabular}

As a result, the development of Malay palace dance more focuses on the creation of intercultural dance which contains multiethnics aspects and fades the original TIM, especially Asyik dance. This is different from TKGY which has rigid standard guidelines and cannot be changed although there are some offers to compromize with other cultures. At the end, this problem can be brought to a higher level related to the Sultan political power.

Kesultanan Yogyakarta has the strongest shadow state in Indonesia and the biggest human resources which are con- 
centrated on the center of economics development. This is difefrent from Malay ethnic in Malaysia; although it is the majority, it is separated into some smaller states in Semenanjung Malaysia area, and does not have power on economics area, like Java in Indonesia.

Chinese people takes the strongest economics power in Malaysia so the enterpreneurs do not see TIM as a cultural object which should be performed on capitalistics activities. In Indonesia, Javanese is a dominant ethnic who has power on economics. There were chinese conglomerate, but assimilatsion process done by Orde Baru could weaken chinese economics power so they have to compromize their ethnical identity with Javanese ethnical identity. We can easily find Chinese speak Javanese well and find it difficult to speak Chinese. Chinese people also change their names into Javanese name, and after reformation era, they try to preserve their Chinese names and other cultural objects.

In a less friendly atmosphere for the development of TIM in Malaysia, giving feedback is more difficult to do. It means that TIM as a palace dance has lost its association with Kraton/palace and finally becomes a dance appointed by Kementerian Pelancongan dan Kebudayaan Malaysia through Jabatan Kesenian in Kelantan, Pahang, and Terengganu. There are two actors left in inheritance process of TIM in Malaysia: formal and non-formal institusion. The following is the situation of TIM in Malaysia compared to TKGY.

\section{CONCLUSION}

Based on the discussion described in the first section, there are some recommendation for formal and non-formal institution to develop Malay Palace dance (TIM). First, formal and nonformal institution need to develop a philosophical foundation for TIM, which is analog to Joget Mataram in TKGY. The philosophical foundation can be abstracted through interdiscipline study by experts in formal institution and in-depth reflection by the experts in non-formal institution related to Malay cultural identity. The philosophical foundation is then implanted in the curriculum of formal education in dancing.

Second, dancers' selection in formal and nonformal institution should be based on their competence, not closeness or ethnics. Although s/he is a Chinese but s/ he is good at Malay dance, s/he should be selected. In TKGY, there is no rule that the dancers should be Javanese, and that should be applied to TIM too. It is difficult to do in a multicultural background country like Malaysia, but it is not impossible. Compromising steps can be done. For example, if Chinese people have to learn TIM, Malay people should also learn to dance Chinese Classical dance (TKT).

In Indonesia, especially in in a Malay area with Chinese people in certain area, like Pontianak and Singkawang, it is not difficult to find Malay ethnic who can do Singa dance well and take part as Singa dancer in capitalistics events and Chinese cultural events. This program can be more effective in inheriting cultural object from various ethnics in Malaysia than reisolating cultural dances from various ethnics and put contemporary dances with multicultural nuances and its movements and stories than the dancers forward.

Thrd, regenaration should be done on formal and nonformal institutio. Young dancers can be easily trained than the older ones. They can be directed to dance TIM correctly and can master it well, than old dancers who are resistant to change. In formal institution which completely has Malay ethnic, TIM can be taught easily and accepted by many parties, and they should take this chance because there will be less class composed by mono ethnic in Malaysia.

Fourth, social orientation must be emphasized. It will be easy as TIM gets less attention from capitalists. However, it will also be difficult thing to do because high dedicated teachers are needed for this social job to teach students to dance TIM with low cost.

Fifth, governments in Malaysia 
should recruit formal and nonformal institusion to do shows in domestic and foreign countries. At this time, this step runs well and is expected to be more intensive quantitatively.

\section{REFERENCES}

Manaf, A., \& Faridah, N. (2002). Tarian Asyik, dalam David Levinson dan Karen Christensen, ed., Encyclopedia of Modern Asia: Vol. 5. New York: Thomson-Gale.

Ibrahim, A. O. H. (2005). Joget Gamelan Terengganu dan Pahang. Kuala Lumpur: Kementerian Kebudayaan, Kesenian, dan Warisan Malaysia.

Ang, M. (2002). An Introduction to Malaysian Music. Kuala Lumpur: Musicmall.

$\mathrm{Au}$, E. (2014). Showbiz: Beneath the Stars. New Straits Times.

Conlon, K. T. (2012). Ethnic Violence in Southern Thailand: the Anomaly of Satun. Monterey: Naval Postgraduate School.

D'Cruz, M. (2011). Joget Gamelan - the Royal Dance of the Pahang and Terengganu Courts. In Mohd Anis Md Nor dan S. Burridge, ed., In Sharing Identities: Celebrating Dance in Malaysia. New Delhi: Routledge.

Gonzales, J. (2008). Tertiary Dance Education in Malaysia. In Lindy Joubert, ed., Educating in the Arts: the Asian Experience. Dodrecht: Springer.

Bakti, I. \& Tharuwat, M. (2011). Asyik Dance: from Kelantanese Palace to a National Heritage. In Mohd Anis Md Nor dan S. Burridge, ed., In Sharing Identities: Celebrating Dance in Malaysia. New Delhi: Routledge.

Kementerian Pengajian Tinggi. (2013). Modul Teras Kebudayaan. Kuala Lumpur: Jabatan Pengajian Tinggi. Kultural, 7(4).

Matusky, Patricia \& Chopyak, J. (2008). Peninsular Malaysia. In Terry E. Miller dan Sean Williams, ed., The Garland Handbook of Southeast Asian Music, New York: Routledge.
Yong, M. \& Christine. (2010). Contesting Boundaries of the Malay Gamelan: the Contemporary Response of Rhythm in Bronze. In Mohd Anis Md Noor, Patricia Matusky, Tan Sooi Beng, Jacqueline-Pugh Kitingan, dan Felicidad Pridenie, ed. Paper presented on Symposium Singapore: ICTM Study Group on

Miles, H. B. \& Huberman, A. M. (1992). Analisis Data Kualitatif. Translated by Tjetjep Rohendi Rohidi. Jakarta: UI Press.

Djamaan, M. N. I. (2003). Tari Melayu Malaysia: Satu kajian berdasarkan Festival Tari Kebangsaan. Desertation. Universiti Malaya.

Nor, M. A. M. (2004). The Relationship of Traditional Malaysian Dance Movements to the Colotomic Unit of $\mathrm{Mu}-$ sic. Paper presented on 37th ICTM World Conference in Fuzhou and Quanzhou, China, January 4-11, 2004.

Nor, M. A. M. (2012). Writing on Hybridity: Re-Exerting Ownership through Dance Writing in Malaysia. In Dancing Mosaic: Issues on Dance Hybridity. Performing Arts of Southeast Asia. Kuala Lumpur: ICTM.

Zakaria, N. W., \& Ibrahim, S. H. (2008). Transkrip Temubual Bersama Datuk Suhaimi bin Mohd Zain mengenai Sumbangan dan Pengalaman Beliau sebagai Seorang Pengubah Lagu. Shah Alam: Universiti Teknologi Mara.

Porntep B., Kla S., \& Prarop K. (2013). The Development of Costumes for ThaiMuslim Folk Performance Arts in Three Southern Border Provinces of Thailand, Asian Social Science, 9(4), 100.

Pusat Kokurikulum dan Pemajuan Pelajar. (2009). Panduan Program Kokurikulum. Sabah: Universiti Malaysia Sabah.

Alfirafindra, R. (2012). Peran Majelis Pusat Pertubuhan-Pertubuhan Budaya Melayu Singapura dalam Festival Tari Serumpun. Joged, 3(1), 78-86.

Thomas, R. \& Sydenham, S. (2008). Cloth- 
ing in Thailand. Retrived from http://www.kidcyber.com.au.

Rohidi, T. T. (2011). Metodologi Penelitian Seni. Semarang: Cipta Prima Nusantara.

Sahimi, M. H. C. (2005). Deskripsi Umum Seni Persembahan Dunia Melayu,
Studi.

Takari, M. (2013). Tradisi Lisan di Alam Melayu: Arah dan Pewarisannya. Paper presented in Seminar Regional Indonesia dan Thailand, Medan: Universitas Sumatera Utara. 